\title{
ASSESSMENT OF BUILDING INFORMATION MODELING UPTAKE IN THE MANAGEMENT OF CONSTRUCTION PROJECTS
}

\author{
RAPHEAL ABIODUN OJELABI, IGNATIUS OWOICHO OMUH, ADEDEJI OLUSHOLA \\ AFOLABI, and PATIENCE FIKIYEMO TUNJI-OLAYENI
}

Dept of Building Technology, Covenant University, Ota, Nigeria

\begin{abstract}
The need for digitization of industries' production process has been given high attention in the 21 st century. This is due to the upsurge in technology in the present age. Industries which include manufacturing, telecommunication and aviation among others have set the pace for others to follow in the use of digital tools in their production process. Therefore, this study is aimed at examining the awareness and level of uptake of a digital tool like Building Information Modeling (BIM) in the management of construction project and the challenges limiting its use within the built environment. The study adopted a survey method by randomly selecting 120 construction practitioners in construction firms operating in Lagos state Nigeria. Likewise, 120 structured questionnaires were distributed to the targeted respondents, however, 100 questionnaires were retrieved. The data collected from the survey were processed using Mean item score, percentage, and relative importance index. Findings garnered from the study revealed that construction organization awareness of the BIM tool is very high, however, its uptake in the construction industry is not encouraging. It further revealed that the driving factor in encouraging the BIM adoption cut across the government, the construction industry and the clients. In conclusion, the study recommends that the trio should provide an adequate support structure and push for BIM implementation in construction project delivery.
\end{abstract}

Keywords: Construction organization, Built environment, Digitization, BIM.

\section{INTRODUCTION}

The construction industry is one of the key sectors across the globe due to its capacity to cause physical transformation of the urban environment (Ojelabi et al. 2017). The industry relevance is evidenced in its deliverables, which are visible in nations across the globe. In a bid to sustain the leading role of the construction industry globally, stakeholders in the industry geared their effort in developing a sustainable system that can enhance the performance of the professional players within the construction industry. Such efforts have led to the development of a digital tool known as Building Information Modeling System (BIM). Takim et al. (2013) asserted that the introduction of BIM in the construction industry has brought about a positive shift in the built environment. The emergence of Building Information Modeling System in the built environment has changed the face of the construction industry. Bui et al. (2016) affirmed that BIM is a catalyst for innovation and accelerated productivity in the built environment.

BIM is a system that adopts computer technology in generating a model capable of causing collaboration as to populate information and stimulate the planning, design, construction, and 
operation of a facility (Construction Industry Development Board 2013, Amusan et al. 2018). The capacity of the system as revealed in the definition, which includes planning, design, construction, and operation provides a powerful synergy that makes it unequal to other software used in the built environment. BIM also has the capacity for collaboration of all stakeholders in the built environment. Prior to the initiation of the BIM system, Lindblad (2013) opined that the construction industry is one of the largest industry with the highest stakeholders and as well the most fragmented across the globe. The solo effort of the different stakeholders in the construction industry is unequal to any other industry in the past. However, the introduction of BIM system has helped foster a high level of collaboration among construction players, which have culminated into prompt and effective project delivery. Roberti and Buckett (2012) affirmed that BIM is an information and technology software initiated to encourage interdisciplinary collaboration and communication among construction professionals in the production of construction facilities.

It is evident that the benefits of BIM in the construction industry are enormous. However, much impact has not been experienced in developing nations built environment compared to the developed nations. This has warranted the study to assess the level of adoption of BIM in the developing nations of the world using Nigeria as a case study and also investigate the driving factors that can encourage BIM implementation.

\section{LITERATURE REVIEW}

The world is referred to as a global village with the advent of information technology (IT). There is no sector across the globe that do not tap into the benefits of information technology. The introduction of information technology in the construction industry is very instrumental to the cutting edge recorded in the built environment. Fischer and Kunz (2006) affirmed that blended history of the construction industry and information technology span between 3 decades and such have accounted for the positive shift experienced in the built environment. The integration of information technology (IT) in the construction industry has led to the development of different software's and BIM falls in the latest and trending software in the industry. Adoption of BIM in the construction process in the built environment has undoubtedly enhanced the performance of the construction professionals in achieving a better and faster delivery of infrastructures. Associated General Contractors of America (2005) affirmed that models generated from BIM system are highly rich in data for use of the individual professional player in the construction industry for analysis to aid their decision making in the delivery of infrastructures. Rokooei (2015) revealed further how instrumental BIM have been in the construction industry due to its capacity to create a common language among construction professionals by making them an integrated team in the process of project delivery. The synergy platform provided by BIM for all players in the construction industry has never been like what is in existence now. Such platforms have however culminated into a geometric increase in the production of infrastructures delivery.

However, despite the introduction of BIM across the globe, its deliverables are unequal probably due to the issue of adoption and implementation among different countries. Developed nations of the world undoubtedly have benefited immensely from the deliverables of BIM due to the visible result in their built environment. Smith (2014)'s study on "global strategies on BIM implementation" revealed that advanced nations of the world gives high credence to the adoption and use of BIM and such have contributed to the massive improvements in their built environment. Wong et al. (2009) identified United State as the leader in the development and implementation of BIM system. Azhar et al. (2008) revealed that $75 \%$ of construction companies in the United States are considering the adoption of BIM and will only employ those with BIM 
skills. Smith (2014) further revealed the stand of General Service Administration (GAS), a body responsible for the management of federal government's facilities as it mandates the use of BIM for all public works in the United State of America. This accounted for the jump in the adoption of the tool from $28 \%$ in 2007 to $71 \%$ in 2012 within the territory of North America (McGraw 2014). It is not surprising why they are referred to as one of the construction leaders in the world. The great transformation in their built environment can be traced to their effort in the adoption and use of sustainable tools like BIM. In the same vein, the United Kingdom is another country that has a significant record in BIM adoption. The country has something in common with the United State in their push for BIM adoption and usage among industry players. HM Government (2012) revealed that the UK government developed a strategy for implementation of BIM in all public projects as they considered it more cost effective and better management tool for construction-related projects. Smith (2014) revealed further that the BIM strategy plan has a significant impact on the stakeholders in the built environment in both public and private sector as they move towards developing manpower technically in order to meet the requirements. Likewise, Shaikh et al. (2016) asserted that countries in the Scandinavian region like Finland, Denmark, and Norway among others also shows remarkable push in the adoption and use of BIM.

Bui et al. (2016) asserted that developed and developing nations are not altogether equal in the adoption and implementation of BIM. Nigeria, for example, is a developing country with a fast-growing population equal to its level of infrastructural development; Nigeria ranked $132^{\text {nd }}$ out of $138^{\text {th }}$ infrastructural strength among nations across the globe (World Economic Forum 2016). It is evident that the construction industry productivity in Nigeria is not encouraging. This can be traced to the poor rate of infrastructures production due to the report of construction projects time and cost overruns, inadequate planning, and budgetary provisions, inefficient and poor service delivery among others. However, Lindblad (2013) revealed that one of the key issues affecting construction industry productivity can be attributed to the fragmentation of the professionals in the industry. In a bid to address the professional fragmentation issue, information and communication technology (ICT) tools are conceived to deal with the shortcoming (Johnson and Laepple 2003). The construction industry in Nigeria has gone through different technological phases, however, the adoption of the latest technological BIM tool is still subject to questioning.

\section{RESEARCH METHODOLOGY}

The study was aimed at assessing the level of adoption and implementation of building information modeling in Nigeria for construction related works in Lagos state. In a bid to achieve the aim, the study set the following objectives to examine the level of awareness and use of BIM and identify the factors that can encourage BIM adoption among the local professional's using the relative importance index (RII) to determine the level of importance of the factors. Data was sourced from both primary and secondary sources. Primary data was obtained with the aid of structured questionnaires administered to the construction professionals in the study area. The sample was selected using purposive sampling technique, one of the non-probabilistic techniques. Construction professionals' views in Lagos were sorted due to their engagement in high numbers of construction works ongoing in the state. A total of 120 questionnaires were distributed.

\section{RESULT AND ANALYSIS}

\subsection{Characteristics of Respondents}

In this section, the personal information of the respondents used for the study was analyzed using percentage. The results obtained are presented in Table 1. 
Table 1. Respondents' characteristics.

\begin{tabular}{lcc}
\hline Characteristics & Frequency & Percentage \\
\hline Academic qualification & 2 & \\
HND & 42 & 2.0 \\
B.Sc/BTech & 56 & 42.0 \\
M.sc/MPM & $\mathbf{1 0 0}$ & 56.0 \\
Total & & $\mathbf{1 0 0}$ \\
Profession & 30 & \\
Architect & 16 & 30.0 \\
Quantity surveyor & 38 & 16.0 \\
Builder & 11 & 38.0 \\
Structural engineer & 5 & 11.0 \\
Electrical engineer & $\mathbf{1 0 0}$ & 5.0 \\
Total & & $\mathbf{1 0 0}$ \\
Years of industrial experience & 37 & \\
1-5 years & 54 & 37 \\
6-10 years & 4 & 54 \\
11-15 years & 4 & 4 \\
16-20 years & 1 & 4 \\
Above 21 years & $\mathbf{1 0 0}$ & 1 \\
Total & & $\mathbf{1 0 0}$ \\
Professional qualification & 37 & \\
NIA & 43 & 37 \\
NIOB & 8 & 43 \\
NIQS & 12 & 8 \\
NSE & $\mathbf{1 0 0}$ & 12 \\
Total & & $\mathbf{1 0 0}$ \\
\hline
\end{tabular}

Table 1 shows the summary of the demographic characteristics of the respondents. It was also discovered that $42 \%$ of the respondents have B.Sc/B.Tech as their academic qualification. Also, 56\% of the respondents have MSc/MPM and only 2\% possesses HND as their highest academic qualification. The analysis shows that the respondents are fairly represented academic wise. The findings further revealed the construction professionals were well represented in the study. Builders have the highest respondents of $38 \%$ followed by Architects with a percentage score of $30 \%$. Quantity surveyors and structural engineers are also fairly represented with the percentage score of $16 \%$ and $11 \%$ respectively while the least professional respondents are the electrical engineers with a percentage score of 5\%. The demographic results also showed that the respondents' industrial experience is sufficient for the study as $54 \%$ of the respondents' years of industrial experience falls within the range of 6-10 years. It was followed by respondents with 15 years of experience with $37 \%$. The professional affiliation of the respondents was also captured and it was revealed that $37 \%$ of the respondents were NIA members, $43 \%$ are NIOB members, $12 \%$ are NSE members and $8 \%$ are NIQS members respectively.

\subsection{Awareness and Use of BIM}

The study revealed the level of awareness and use of BIM among the local professionals. The findings revealed that the level of awareness is not bad, but the usage level of BIM is very low. It is evidenced from the result in Table 2 that only $12 \%$ of the respondents are not aware of BIM, 
however, $83 \%$ are aware of the software but are not using it while the percentage of respondents using it are $5 \%$ as revealed from the study.

Table 2. Level of BIM awareness and use.

\begin{tabular}{lcc}
\hline BIM awareness and use & Frequency & Percent \\
\hline Not aware & 12 & 12.0 \\
Aware and using BIM & 5 & 5.0 \\
Aware but not using BIM & 83 & 83.0 \\
Total & $\mathbf{1 0 0}$ & $\mathbf{1 0 0 . 0}$ \\
\hline
\end{tabular}

\subsection{Factors Encouraging BIM Adoption and Implementation}

This section reveals the varying factors that can encourage BIM adoption and implementation. The factors are ranked in accordance to their level of importance as presented in Table 3.

Table 3. BIM drivers.

\begin{tabular}{lcc}
\hline & RII & Rank \\
\hline Affordability of BIM software. & 0.98 & 1 \\
Government enforcement support in the & 0.95 & 2 \\
adoption and implementation of BIM. & 0.91 & 3 \\
Increasing investment in BIM software. & 0.87 & 4 \\
Competitive pressure. & 0.86 & 5 \\
Client pressure. & 0.86 & 5 \\
Availability of BIM training programs. & 0.85 & 6 \\
Attaching benefits to BIM competency. & 0.82 & 7 \\
Mandate construction staff to be BIM & & \\
competent. & 0.82 & 7 \\
Creating an organizational structure that & 0.78 & 8 \\
supports BIM. & & \\
Grant provision scheme for BIM training. & & \\
\end{tabular}

It is evidenced from the results that all the identified factors are significantly important as their relative importance values are all above 0.70. However, three of the factors have remarkably high importance index value above 0.90 and they are affordability of BIM software, government enforcement support in the adoption and implementation of BIM and increasing investment in BIM software with 0.98, 0.95, and 0.91 importance index respectively.

\section{CONCLUSION AND RECOMMENDATION}

The findings from the study revealed that the level of awareness of BIM among the construction experts is very high; however, its implementation in the construction industry is very poor. To enhance the tool adoption, factors that can contribute to the BIM implantation were assessed and the findings revealed that the drivers cut across the construction industry, clients, and the government. Therefore, the study recommends that it is essential for the three parties to collaborate in a bid to enhance the implementation of the tool within the built environment. 


\section{Acknowledgments}

The researchers appreciate the publication support fund given by Covenant University towards the publication of this article.

\section{References}

Amusan, L., Ezewinwe, O., Osawaru, F., Joshua, O., Afolabi, A., and Ojelabi, R., Creating Sustainable Construction: Building Informatics Modelling and Lean Construction Approach, Journal of Theoretical and Applied Information Technology, 96(10), 3025-3035, 2018.

Associated General Contractors of America, The Contractor's Guide to BIM, 1st Ed., AGC Research Foundation, Las Vegas, NV, 2005.

Azhar, S., Hein, M., and Sketo, B., Building Information Modelling (BIM): Risks and Challenges, Proceedings of the $144^{\text {th }}$ ASC Annual Conference, Aurburn, Alabama, 2008.

Bui, N., Merschbrock, C., and Munkvold, B. E., A Review of Building Information Modelling for Construction in Developing Countries, Procedia Engineering, 164, 487-494, 2016.

Construction Industry Development Board, Workshop of BIM Portal and Collaboration Platform for Affordable BIM, Holiday Inn Glenmarie, Shah Alam, Selangor, Kuala Lumpur, January 9-11, 2013.

Fischer, M., and Kunz, J., The Scope and Role of Information Technology in Construction, 2006. Retrieved from http:cife.stanford.edu/online.publications/TR156.pdf on June 15, 2018.

HM Government, Building Information Modelling, Industrial Strategy- Government and Industry in Partnership, Government Report, London, 2012.

Johnson, R. E., and Laepple, E. S., Digital Innovation and Organizational Change in Design Practice, CRS Center, Texas A \& M University, 2003.

Lindblad, H., Study of the Implementation Process of BIM in Construction Projects, 2013. Retrieved from http://kth.diva-portal.org/smash/get/diva2:633132/FULLTEXTD1 on July 22, 2018.

McGraw, H., The Business Value of BIM for Construction in Major Global Markets: How Contractors Around the World Are Driving Innovation with Building Information Modelling, Smart Market Reports, 2014.

Ojelabi, R. A., Oyeyipo, O., and Afolabi, A. O., Built Environment Professionals' Perception of the Effectiveness of Building Control Measures in Lagos State, Journal of Construction in Developing Countries, 22(1), 41-54, 2017.

Roberti, J., and Buckett, N., Analysis of the BIM Issues as a Basis for a BRANZ Research Program, Memorandum, BRANZ, Wellington, New-Zealand, 2012.

Rokooei, S., Building Information Modelling in Project Management: Necessities, Challenges and Outcomes, Procedia-Social and Behavioral Sciences, 210, 87-95, 2015.

Shaikh, A. A., Raju, R., Malim, N. L., and Jayaraj, G. K., Global Status of Building Information Modelling (BIM) - A Review. International Journal on Recent and Innovation Trends in Computing and Communication, 4, (3), 300-303, 2016.

Smith, P., BIM Implementation - Global Strategies, Procedia Engineering, 85, 482-492, 2014.

Takim, R., Harris, M., and Nawawi, A. H., Building Information Modelling (BIM): A New Paradigm for Quality of Life within Architectural Engineering and Construction (AEC) Industry, Procedia-Social and Behavioral Sciences, 101, 23-32, 2013.

Wong, A., Wong, F., and Nadeem, A., Comparative Roles of Major Stakeholders for the Implementation of BIM in Various Countries, Hong Kong Polytechnic University, Hong Kong, 2009.

World Economic Forum, The Global Competitiveness Report, 2016. Retrieved from www.weforum.org/gcr on July 3, 2018. 